\title{
RESULTS OF STUDYING ROAD CONSTRUCTION PARAMETERS' CONDITION
}

\author{
Elena Kurakina ${ }^{1}$, Stanislav Evtyukov ${ }^{2}$ \\ 1,2 Saint Petersburg State University of Architecture and Civil Engineering \\ Vtoraja Krasnoarmejskaja ul. 4, St. Petersburg, Russia \\ 1elvl_86@mail.ru
}

\begin{abstract}
A system for the accounting of road infrastructure facilities' parameters specified during design and construction of motor roads. A study of parameters' condition was performed. Analysis of road accident rate statistics and identification of parameters to assess the efficiency of the proposed road construction activities aimed at the reduction in the number of road accidents were carried out.

Actual data on condition parameters with the use of modern automated multi-functional diagnostic equipment were obtained. Actions aimed at the improvement of road infrastructure parameters through traffic safety enhancement, as well as actions aimed at the reconstruction of the motor road or project-supported construction of road segments were developed. Efficiency of the proposed actions was assessed.
\end{abstract}

\author{
Keywords \\ Motor road, construction, reconstruction, road surface, vehicle, parameters, road accidents.
}

\section{Introduction}

Obtaining of studies results is based on the use of the improved system for accounting of parameters during design and construction of motor roads. Non-compliance with construction regulations has adverse effects during operation. In particular, it can lead to premature destruction of the road surface, appearance of rutting, low adhesion characteristics of the road surface, certain condition of the roadway and shoulders (especially in winter), producing accident-prone situations.

Generally, such factors decrease traffic safety decrease and increase the number of road accidents. Troubleshooting reduces to expert study which represents a set of successive systematic theoretical and practical methods or actions aimed at identifying the causes and factors that led to a failure in the Driver-Vehicle-RoadEnvironment (DVRE) system.

A failure in the system means operating trouble of one of the key components, i.e. Vehicle, Driver, Road or their combinations, including the Environment component, which, in their turn, cease to perform their assigned functions partially or totally, leading to violations in safe operation of the entire system.

Analysis of operating troubles or failure prevention are possible through qualitative expert study. Scientific studies of some parameters of the subsystem "Vehicle-
Road" condition, performed by scientists Nemchinov M. V., Vasiliev A. P., and Domke E. R., are aimed at braking performance and characteristics of wheel adhesion with the road surface during operation and reconstruction of the latter (Kurakina, Evtyukov, 2017; Domke, 2012; Evtyukov, Vasiliev, 2012; Kurakina, 2014b; Suvorov et al., 1990). Scientists Suvorov Yu. B., Kikot I. M. and others (Evtyukov, Vasiliev, 2012; Kurakina, Evtyukov, 2015) were engaged in diagnostic studies of elements of operated motor roads at segments where road conditions affected traffic safety.

Kiryukhin G. N. proved the relevance of road surface diagnostics and determination of traffic flow characteristics with the use of a wide range of devices and equipment for testing and diagnostics of motor roads (Kurakina, 2016, 2017, Kurakina, Evtyukov, 2014, 2015).

Expert study is supported by various procedures, algorithms, methods, strategies, techniques and equipment, depending on the purpose of the expert study, its complexity and the number of questions posed. Subjects of various researches are reviewed in works of such scientists as Borovskiy B. E., Ilarionov V. A., Evtyukov S. A., Zamarayev I. V., and Stolyarov V. V. (Ilarionov, 1989; Kurakina, 2014b; Kurakina, Evtyukov, 2015).

However, during construction, the system of accounting for the main parameters of the "Road" subsystem is 
specified by regulatory documents of the construction industry.

Mutual comprehensive studies of parameters conditions shall be carried out at all stages of construction, operation and reconstruction in order to preventemergency conditions (Kurakina, 2014a; Kurakina, Evtyukov, 2014; Kurakina, Evtyukov, 2015; Kurakina et al., 2017; ROSDORNII, 2015; Suvorov et al., 1990). Based on such study, actions aimed at the improvement of road infrastructure parameters through traffic safety enhancement, as well as actions aimed at the reconstruction of the motor road or projectsupported construction of road segments are developed.

\section{Subject, tasks and methods}

The study subject is parameters of above-ground transport and road infrastructure facilities' condition, as well as the number of road accidents as a result of their adverse effect.

The study tasks include the following:

- analysis of road accident rate statistics and identification of parameters to assess the efficiency of the proposed road construction activities aimed at the reduction in the number of road accidents;

- obtaining actual data on condition parameters with the use of modern automated multi-functional diagnostic equipment;

- development of actions aimed at the improvement of road infrastructure parameters through traffic safety enhancement, as well as actions aimed at the reconstruction of the motor road or project-supported construction of road segments;

- assessment of the efficiency of the proposed actions.

Methods for implementing the set tasks include methods of analysis of properties and opportunities for improvement of complex multi-functional systems, such as statical and systematic methods, mathematical methods, computational methods, probability theory, data processing theory with regard to research results, and information technologies.

\section{Results and discussion}

The Driver-Vehicle-Road-Environment (DVRE) system operates due to dynamic road infrastructure parameters and environmental conditions, motor vehicles' specifications and processes, psychophysiological state of drivers, and continuous system monitoring of changing processes. The main task of such system monitoring is to prevent road accidents and reduce severity of their consequences. As known, a road accident is a complex mechanism of interaction between "Vehicle-Vehicle", "Vehicle-Road", "Vehicle-Pedestrian", and "VehicleEnvironment" subsystems. Circumstances, causes and factors of road accidents are examined at the global expert level.

Road accident rate statistics are analyzed with an analytical approach including the safety factor method, accident rate factor method, and black spot identification method (Table 1).

Table 1. Methods applied to analyze "Vehicle-Road" subsystem parameters with an analytical approach

\begin{tabular}{|c|c|c|c|}
\hline No & Method & $\begin{array}{l}\text { Characterizing } \\
\text { parameters }\end{array}$ & $\begin{array}{l}\text { Analyzed "Vehicle- } \\
\text { Road" subsystem } \\
\text { parameters }\end{array}$ \\
\hline 1 & $\begin{array}{l}\text { Safety factor } \\
\text { method }\end{array}$ & $\begin{array}{l}\text { Maximum traffic } \\
\text { speed at the ana- } \\
\text { lyzed motor road } \\
\text { segment }-V_{\max }^{\text {traffic }} \\
\text { vehicle's initial } \\
\text { speed }-V_{\text {initial }}\end{array}$ & $\begin{array}{l}\text { Traffic intensity. } \\
\text { Shoulder-to-shoulder } \\
\text { width and width of } \\
\text { shoulders. } \\
\text { Clear vision distance } \\
\text { (plan and profile } \\
\text { views). } \\
\text { Longitudinal grade. } \\
\text { Curve radius in the } \\
\text { road cross-section } \\
\text { (on long ascending } \\
\text { grades) }\end{array}$ \\
\hline 2 & $\begin{array}{l}\text { Accident rate } \\
\text { factor method }\end{array}$ & $\begin{array}{l}\text { Partial accident rate } \\
\text { factors }-K_{i}\end{array}$ & $\begin{array}{l}\text { Results of road } \\
\text { accident statistical } \\
\text { analysis. } \\
\text { Traffic intensity. } \\
\text { Shoulder-to-shoulder } \\
\text { width and width of } \\
\text { shoulders. } \\
\text { Number of traffic } \\
\text { lanes. } \\
\text { Clear vision distance } \\
\text { (plan and profile } \\
\text { views). } \\
\text { Longitudinal grade. } \\
\text { Clear vision (plan and } \\
\text { profile views). } \\
\text { Vertical curves (plan } \\
\text { view). } \\
\text { Grade separation. } \\
\text { Road surface con- } \\
\text { dition. }\end{array}$ \\
\hline 3 & $\begin{array}{l}\text { Black spot } \\
\text { identification } \\
\text { method }\end{array}$ & $\begin{array}{l}\text { Absolute and rela- } \\
\text { tive number of road } \\
\text { accidents }\end{array}$ & $\begin{array}{l}\text { Traffic intensity. } \\
\text { Results of road acci- } \\
\text { dents with injuries. }\end{array}$ \\
\hline
\end{tabular}

In the field of road construction, motor road operation and reconstruction, it is necessary to take into account the system of parametric characteristics of objects and conditions for their existence:

- geometry of road environment facilities (GREF);

- transport and operating conditions (TrOC);

- technical and operating conditions (TechOC);

- characteristics of road infrastructure facilities (CRIF).

Obtaining information about GREF, TrOC, TechOC, and CRIF is possible by means of diagnostic and computational methods of obtaining and processing 
of parametric characteristics (Kurakina, Evtyukov, 2017; Kurakina, 2014, 2016; Kurakina, Evtyukov, 2015, ROSDORNII, 2015) (Table 2).

Table 2. Methods applied to analyze parameters with diagnostic and computational methods

\begin{tabular}{|c|c|c|c|}
\hline \multicolumn{4}{|c|}{ Diagnostic method } \\
\hline 1 & $\begin{array}{l}\text { Systematic } \\
\text { monitoring }\end{array}$ & $\begin{array}{l}\text { Usability of motor } \\
\text { roads. } \\
\text { Specified time } \\
\text { intervals. }\end{array}$ & $\begin{array}{l}\text { Shoulder-to-shoulder } \\
\text { width and width of shoul- } \\
\text { ders. } \\
\text { Clear vision distance (plan } \\
\text { and profile views). } \\
\text { Longitudinal grade. } \\
\text { Clear vision (plan and } \\
\text { profile views). } \\
\text { Vertical curves (plan } \\
\text { view). } \\
\text { Curve radii. } \\
\text { Road surface evenness } \\
\text { and strength. } \\
\text { Adhesion characteristics. }\end{array}$ \\
\hline 2 & $\begin{array}{l}\text { Method for } \\
\text { determination } \\
\text { of transverse } \\
\text { evenness } \\
\text { of the road } \\
\text { surface }\end{array}$ & $\begin{array}{l}\text { Clearance } \\
\text { between the road } \\
\text { surface and the } \\
\text { bottom surface } \\
\text { of the leveling } \\
\text { beam; clearance } \\
\text { between the } \\
\text { road surface and } \\
\text { the profilograph } \\
\text { wheel. }\end{array}$ & $\begin{array}{l}\text { Road surface evenness. } \\
\text { Rutting. }\end{array}$ \\
\hline 3 & $\begin{array}{l}\text { Dynamometer } \\
\text { method for } \\
\text { determining } \\
\text { evenness } \\
\text { of the road } \\
\text { surface }\end{array}$ & $\begin{array}{l}\text { Clearance } \\
\text { between the } \\
\text { road surface and } \\
\text { the PKRS-2U } \\
\text { (evenness and } \\
\text { adhesion inspec- } \\
\text { tion tool with an } \\
\text { oscillograph) } \\
\text { wheel }\end{array}$ & Road surface evenness. \\
\hline 4 & $\begin{array}{l}\text { Method for } \\
\text { determining the } \\
\text { road/tire adhe- } \\
\text { sion coefficient }\end{array}$ & $\begin{array}{l}\text { Maximum rim } \\
\text { pull. } \\
\text { Vertical load on } \\
\text { the road surface. } \\
\text { Registration } \\
\text { using PPK, } \\
\text { IKSp-m (portable } \\
\text { instruments for } \\
\text { adhesion coeffi- } \\
\text { cient measuring). }\end{array}$ & Adhesion coefficient \\
\hline 5 & $\begin{array}{l}\text { Method for } \\
\text { determining } \\
\text { roughness } \\
\text { of the road } \\
\text { surface }\end{array}$ & $\begin{array}{l}\text { Average valley } \\
\text { depth }\end{array}$ & $\begin{array}{l}\text { Valley depth roughness } \\
\text { affecting the adhesion } \\
\text { coefficient }\end{array}$ \\
\hline
\end{tabular}

\begin{tabular}{|l|l|l|l|}
\hline 6 & $\begin{array}{l}\text { Georadar } \\
\text { sounding of } \\
\text { road structure }\end{array}$ & $\begin{array}{l}\text { Georadar } \\
\text { profile with road } \\
\text { structure density } \\
\text { fluctuations }\end{array}$ & $\begin{array}{l}\text { Depth of road structural } \\
\text { layers. } \\
\text { Landslide curve location. }\end{array}$ \\
\hline 7 & $\begin{array}{l}\text { Method for } \\
\text { determining } \\
\text { strength of the } \\
\text { road structure }\end{array}$ & $\begin{array}{l}\text { Elastic deflection } \\
\text { value. } \\
\text { Area of contact } \\
\text { with the road } \\
\text { surface. } \\
\text { Falling weight } \\
\text { characteristics. }\end{array}$ & $\begin{array}{l}\text { Road surface strength } \\
\text { and reliability. } \\
\text { Elastic deflection of the } \\
\text { road structure. }\end{array}$ \\
\hline 8 & $\begin{array}{l}\text { Core sampling } \\
\text { method }\end{array}$ & $\begin{array}{l}\text { Elastic deflection } \\
\text { value. } \\
\text { Drilling bit char- } \\
\text { acteristics. }\end{array}$ & $\begin{array}{l}\text { Road surface strength } \\
\text { and reliability. } \\
\text { Elastic deflection of the } \\
\text { road structure. }\end{array}$ \\
\hline 1 & $\begin{array}{l}\text { Automated } \\
\text { calculation and } \\
\text { analysis }\end{array}$ & $\begin{array}{l}\text { Computational method } \\
\text { software }\end{array}$ & $\begin{array}{l}\text { Transport, technical and } \\
\text { operating parameters. } \\
\text { Road accident registration } \\
\text { and analysis. }\end{array}$ \\
\hline 2 & $\begin{array}{l}\text { Method of pan- } \\
\text { oramic video } \\
\text { shooting of } \\
\text { motor roads }\end{array}$ & $\begin{array}{l}\text { Specifications of } \\
\text { digital cameras, } \\
\text { performed linear } \\
\text { measurements }\end{array}$ & $\begin{array}{l}\text { Shoulder-to-shoulder } \\
\text { width and width of shoul- } \\
\text { ders. } \\
\text { Availability of cracks, } \\
\text { potholes, and other types } \\
\text { of damage in the road } \\
\text { surface. }\end{array}$ \\
\hline
\end{tabular}

Mathematically, the model of expert study implementation with account for parameters can be represented in the following form:

$\mathrm{Y}=f(\mathrm{X})$

where $X$ - parameters applied and obtained during the study.

Taking into account methods of obtaining and processing of parameters during the study, the value $X$ of the sum of all characteristics and conditions can be represented in the following form:

$$
\left\{\begin{array}{l}
\sum_{i=1}^{n} X^{A}=f\left(x_{i}^{A}\right), \\
\sum_{i=1}^{n} X^{D}=f\left(x_{i}^{D}\right), \\
\sum_{i=1}^{n} X^{C}=f\left(x_{i}^{C}\right)
\end{array}\right\},
$$

where $f\left(x_{i}^{A}\right)$ are parameters, their characteristics and conditions determined analytically, i.e. $f\left(x_{i}^{D}\right)$ are determined diagnostically and $f\left(x_{i}^{C}\right)$ are determined with computational methods, $i$ is the number of obtained values of the studied parameters.

Taking into account equation 2, we obtain a set of values of parameters, obtained during studies with analytical, diagnostic and computational methods. 
Therefore, taking into account equation 1 and parameters to be determined, the accounting during the expert study, involving numerous parameter values,

will be characterized by parameters involved in the study.

Evaluation of parametric characteristics of objects and conditions represents an expert opinion on the results of the study aimed at the following:

- accident rate at the analyzed road section;

- black spot identification on motor roads;

- identification of "weak" motor road segments to determine the qualitative component of the road infrastructure, in particular, the load-bearing capacity of the road structure. Identification of road surface defects, deflections, and moduli of elasticity to determine its remaining life.

- development of an automated road data base (ARDB) on "weak" motor road segments to raise awareness and improve expert study quality;

- compliance of the obtained values of vehicle and road infrastructure condition parameters with the requirements of regulatory documents;

- determination of road accident risks.

The dependence of the study, conducted by a diagnostic method, during which condition parameters were determined, has the following form:

$\mathrm{Y}\left(X^{D}\right)=f\left(N_{i}, W_{\text {pull. }}, W_{m \text { arg. }}^{\text {sh. }}, W_{\text {div.str. }}^{\text {cent. }}\right.$,

$S_{\text {marg }}^{s h}, L_{\text {stop. }}, i, i_{\text {trans }}, i_{r}, R_{\text {curve }}, S_{\text {cl }}, R_{\text {convex }}, R_{\text {concave }}$,

$Z, h_{f}, L_{\text {slope }}, I_{\text {veh }}, M_{1} \div O_{2}, V_{a}, G_{\text {veh }}, K_{P}^{I-V}$,

$N_{a c c}, A C C_{a b s}, A C C_{r e l}, \phi, t, r, r_{h}, E$,

$\left.D_{\text {r.s. }}, T_{\text {a.s. }}, T_{\text {drain }}, T_{\text {loc }}^{\text {signs }}, T_{\text {light }}, \grave{O}_{\text {rail }}, M T O R T\right)$,

where $N_{i}$ is the number of lanes;

$W_{p u l l}$ is the pullover width;

$W_{m a r g}^{s h}$ is the width of the margin strip of the shoulder, $\mathrm{m}$

$W_{d i v . s t r}^{c e n t}$ is the width of the central dividing strip, m;

$S_{m \text { arg }}^{s h}$ is the margin strip of the shoulder, m;

$L_{\text {stop }}$ is the stopping strip, m;

$i$ is the longitudinal grade, per mille;

$i_{\text {trans }}$ is the transverse grade, per mille;

$i_{r}$ is the raised curve grade, per mille;

$R_{\text {curve }}$ is the curve radii in plan, $\mathrm{m}$;

$S_{c l}$ is the clear vision distance to the object, $\mathrm{m}$;
$R_{\text {convex }}$ is the radii of convex curves in profile, $\mathrm{m}$;

$R_{\text {concave }}$ is the radii of convene curves in profile, $\mathrm{m}$;

$Z$ is the structure of the road bed;

$h_{f}$ is the depth of fill, $\mathrm{m}$;

$h_{e}$ is the depth of excavations, m;

$\angle_{\text {slope }}$ is the slope grade;

$I_{v e h}$ is traffic intensity, vehicles/day;

$M_{1} \div O_{2}$ the categories of vehicles from $M_{1}$ to $O_{2}$;

$V_{a}$ is the vehicle speed, $\mathrm{km} / \mathrm{h}$;

$G_{v e h}$ is the vehicle mass, t;

$K_{P}^{I-V}$ is the coefficient of braking performance of the vehicle;

$N_{a c c}$ is the number of road accidents;

$A C C_{a b s}$ is the absolute accident rate;

$A C C_{r e l}$ is the relative accident rate;

$\varphi$ is the road/tire adhesion coefficient;

$t$ is the rut depth (road surface rutting (wheel tracking)), $\mathrm{cm}$;

$r$ is the roughness of the road surface, average height of material projection, $\mu \mathrm{m}$;

$r_{h}$ is the hydraulic roughness;

$E$ is the modulus of elasticity, $\mathrm{MPa}$;

$D_{r . s .}$ are defects of the road surface;

$T_{\text {a.s. }}$ are artificial structures;

$T_{\text {drain }}$ is the condition of the drainage system;

$T_{\text {loc }}^{\text {signs }}$ is presence of driver location signs;

$T_{\text {light }}$ is availability of lighting;

$T_{\text {rail }}$ is presence of railway crossings;

MTORT is equipping with technical means of road traffic organization.

The algorithm of the study on the analyzed system is presented in Figure 1. 


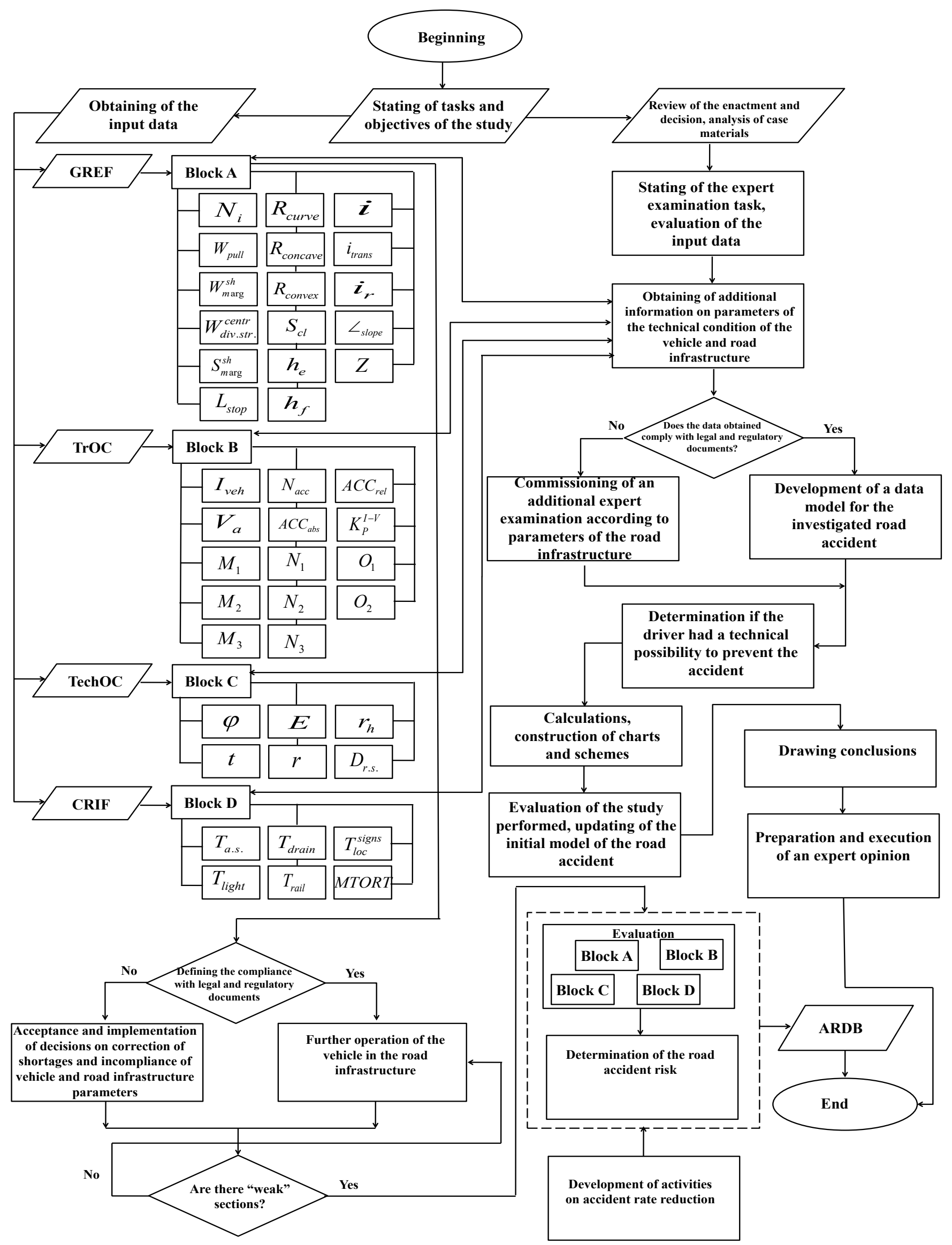

Figure 1. Algorithm of the study on the road infrastructure parameters' condition 


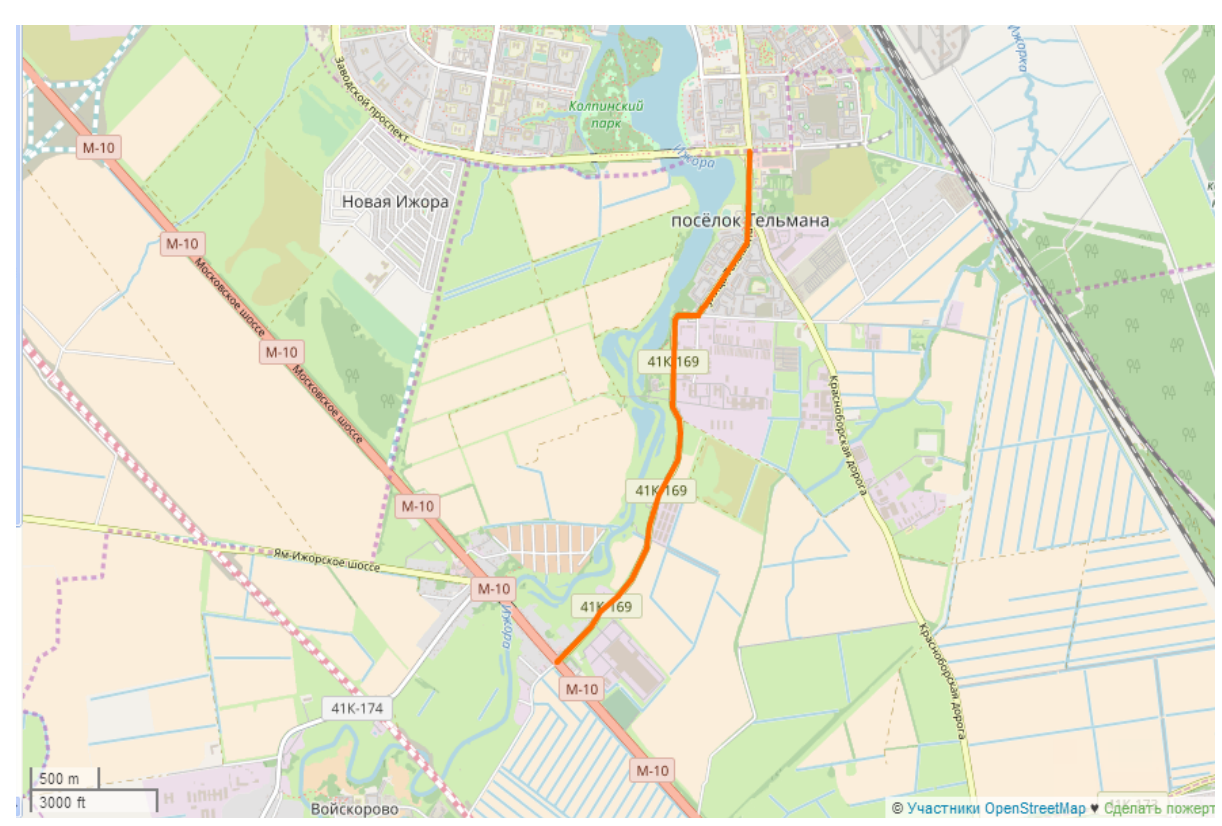

Figure 2. Location of the "Approach to Kolpino" road running in the Tosno District

The development of actions aimed at the improvement of road infrastructure parameters through traffic safety enhancement, as well as actions aimed at the reconstruction of the motor road or project-supported construction of road segments, is illustrated by an example of the "Approach to Kolpino" motor road segment.

The "Approach to Kolpino" regional public road running across the territory of the Tosno District (Figure 2). Length $-4,065 \mathrm{~km}$ (road No. 41K-169). An entrance from the Kolpino District of Saint Petersburg to the Russia M-10 federal public road (Moscow-Tver-Veliky Novgorod-SPb)
In 2016, 7 registered road accidents with injuries occurred on the "Approach to Kolpino" road, 1 accident cluster (black spot) was distinguished for analysis.

A list of actions aimed at black spot elimination was developed.

The corresponding actions were classified into three categories: low-cost, medium-cost and high-cost actions.

Table 3 presents general data on black spots where accidents with injuries occurred during the analyzed period.

Table 3. Condition of parameters at the "Approach to Kolpino" road segment

\begin{tabular}{|c|c|c|c|c|c|c|c|c|}
\hline \multicolumn{9}{|c|}{ Black spot address } \\
\hline \multicolumn{3}{|c|}{ Motor road } & \multicolumn{2}{|c|}{$\begin{array}{l}\text { Start of the segment, } \\
\qquad \mathrm{km}+\mathrm{m}\end{array}$} & \multicolumn{2}{|c|}{$\begin{array}{l}\text { End of the } \\
\text { segment, } \\
\mathrm{km}+\mathrm{m}\end{array}$} & \multicolumn{2}{|r|}{ Length of the segment, $m$} \\
\hline \multicolumn{3}{|c|}{ "Approach to Kolpino" } & \multicolumn{2}{|c|}{$3+400$} & \multicolumn{2}{|c|}{$4+400$} & \multicolumn{2}{|r|}{1,000} \\
\hline \multicolumn{9}{|c|}{ Black spot characteristics } \\
\hline \multirow[t]{3}{*}{ No } & \multirow[t]{3}{*}{ Date } & \multirow[t]{3}{*}{ Time } & \multirow[t]{3}{*}{ Type } & \multirow{3}{*}{$\begin{array}{l}\text { Location, } \\
k m+m\end{array}$} & \multicolumn{3}{|c|}{ Injured } & \multirow[t]{3}{*}{ Poor road conditions } \\
\hline & & & & & \multirow{2}{*}{$\begin{array}{l}\text { Fatali- } \\
\text { ties }\end{array}$} & \multicolumn{2}{|c|}{ Injuries } & \\
\hline & & & & & & Total & $\begin{array}{l}\text { incl. children } \\
\text { with injuries }\end{array}$ & \\
\hline 1 & 10.06 .2016 & $10: 25$ & $\begin{array}{l}\text { Vehicle/pedestrian } \\
\text { accident }\end{array}$ & $3+900$ & 1 & - & - & $\begin{array}{l}\text { Absence or poor visibility of horizontal } \\
\text { signalization }\end{array}$ \\
\hline 2 & 18.02 .2016 & $8: 00$ & $\begin{array}{l}\text { Vehicle/pedestrian } \\
\text { accident }\end{array}$ & $3+440$ & - & 1 & 1 & $\begin{array}{l}\text { Absence or poor visibility of horizontal } \\
\text { signalization }\end{array}$ \\
\hline 3 & 20.10 .2016 & $18: 10$ & $\begin{array}{l}\text { Collision with a } \\
\text { standing vehicle }\end{array}$ & $3+820$ & - & 1 & - & $\begin{array}{l}\text { Absence of shortcomings in transport and } \\
\text { operating conditions of the roadway }\end{array}$ \\
\hline 4 & 28.08 .2016 & $18: 20$ & $\begin{array}{l}\text { Vehicle/pedestrian } \\
\text { accident }\end{array}$ & $3+400$ & - & 1 & 1 & $\begin{array}{l}\text { Absence or poor visibility of horizontal } \\
\text { signalization }\end{array}$ \\
\hline 5 & 23.09 .2016 & $20: 40$ & $\begin{array}{l}\text { Vehicle/bicycle } \\
\text { accident }\end{array}$ & $4+030$ & - & 1 & - & $\begin{array}{l}\text { Absence or poor visibility of horizontal } \\
\text { signalization }\end{array}$ \\
\hline
\end{tabular}


Table 4. Data on black spots on the "Approach to Kolpino" road $3+400-4+400$

\begin{tabular}{|c|c|}
\hline \multicolumn{2}{|c|}{ "Approach to Kolpino" road $3+900$ - vehicle/pedestrian accident } \\
\hline Traffic violation / concurrent traffic violations & $\begin{array}{l}\text { Jaywalking with a crosswalk in sight or an underground (ground level) } \\
\text { crosswalk in close vicinity }\end{array}$ \\
\hline Street and road network facilities & Road section \\
\hline Road conditions: & \\
\hline weather conditions & Clear weather \\
\hline roadway condition & Dry \\
\hline lighting & Day-time \\
\hline \multicolumn{2}{|c|}{ "Approach to Kolpino" road $3+440-$ vehicle/pedestrian accident } \\
\hline Traffic violation / concurrent traffic violations & $\begin{array}{l}\text { Jaywalking with a crosswalk in sight or an underground (ground level) } \\
\text { crosswalk in close vicinity }\end{array}$ \\
\hline Street and road network facilities & Road section \\
\hline \multicolumn{2}{|l|}{ Road conditions: } \\
\hline weather conditions & Clear weather \\
\hline roadway condition & Treated with deicing agents \\
\hline lighting & Day-time \\
\hline \multicolumn{2}{|c|}{ "Approach to Kolpino" road $3+820-$ collision with a standing vehicle } \\
\hline Traffic violation / concurrent traffic violations & Failure to keep distance \\
\hline Street and road network facilities & Road section \\
\hline \multicolumn{2}{|l|}{ Road conditions: } \\
\hline weather conditions & Clear weather \\
\hline roadway condition & Dry \\
\hline lighting & Day-time \\
\hline \multicolumn{2}{|c|}{ "Approach to Kolpino" road $3+400-$ vehicle/pedestrian accident } \\
\hline Traffic violation / concurrent traffic violations & $\begin{array}{l}\text { Violation of rules for driving across the crosswalk / non-compliance with } \\
\text { mandatory vehicle insurance requirements }\end{array}$ \\
\hline Street and road network facilities & Unsignalized crosswalk \\
\hline \multicolumn{2}{|l|}{ Road conditions: } \\
\hline weather conditions & Clear weather \\
\hline roadway condition & Dry \\
\hline lighting & Day-time \\
\hline \multicolumn{2}{|c|}{ "Approach to Kolpino" road $4+030$ - vehicle/bicycle accident } \\
\hline Traffic violation / concurrent traffic violations & $\begin{array}{l}\text { Disregard of priority rules/violation of vehicle arrangement on the road- } \\
\text { way/alcohol-impaired driving }\end{array}$ \\
\hline Street and road network facilities & Departure from the adjacent territory \\
\hline \multicolumn{2}{|l|}{ Road conditions: } \\
\hline weather conditions & Clear weather \\
\hline roadway condition & Dry \\
\hline lighting & Night-time, lighting is on \\
\hline
\end{tabular}

Results of full-scale study of the black spot on the "Approach to Kolpino" road $3+400-4+400$

1. Low quality of shoulder maintenance, availability of potholes filled with water.

2. Road surface shortcomings and defects, rutting.

3. Absence or poor visibility of horizontal signalization.

4. Traffic signalization is maintained on the road segment.

Actions aimed at elimination of the black spot on the "Approach to Kolpino" road $3+400-4+400$ were developed.
For elimination of black spots, the following priority actions were developed with expected accident rate reduction (\%) as a result of their implementation:

- installation of priority traffic signs, prohibitory signs and warning signs for speed reduction, informing of approach to a crosswalk, children crossing zone, dangerous corner $-34 \%$;

- marking of horizontal signalization with wearresistant materials;

- marking of prohibitory and warning signs on the road surface; 
- installation of traffic lights T.7 in zones where pedestrians cross the roadway, marked with horizontal signalization 1.14.1 and traffic signs 5.19.1, 5.19.2 "Crosswalk" to increase focus of drivers when approaching a crosswalk and raise their vigilance upon its passage $-10 \%$;

- arrangement of sidewalks to improve pedestrian traffic safety and avoid vehicle/pedestrian accidents $-23 \%$;

- arrangement of guardrails along sidewalks, in pickup and drop-off areas, in crosswalk areas to avoid vehicle/ pedestrian accidents and ensure safe pedestrian traffic $-25 \%$.

Priority forward-looking actions:

- arrangement of lighting along the road and in pedestrian traffic zones to improve visibility and detection of vertical and horizontal signalization $-25 \%$;

- road surface restoration (road paving) $-21 \%$ in case of 2 lanes, $59 \%$ in case of more than 2 lanes.

Mandatory actions aimed at traffic safety improvement shall comply with the GOST R 50597 requirements to operating conditions acceptable in a safe traffic environment.

Efficiency of the proposed actions is described in Table 4 (with account for low-, medium- and high-cost actions). Changes in condition parameters after implementation of actions at the black spot of the "Approach to Kolpino" road $3+400-4+400$ are assessed.

Table 5. Efficiency of the proposed actions

\begin{tabular}{|l|l|}
\hline \multicolumn{1}{|c|}{ Low-cost actions } & \multicolumn{1}{c|}{ Costs: 151,212.44 } \\
\hline $\begin{array}{l}\text { Approximate assessment of } \\
\text { impact, reduction in the number } \\
\text { of registered road accidents }\end{array}$ & $-41 \%$ \\
\hline $\begin{array}{l}\text { Expected annual effect in case } \\
\text { of implementation of actions; } \\
\text { reduction by: }\end{array}$ & 0.41 fatalities \\
\cline { 2 - 2 } $\begin{array}{l}\text { Annual savings in case of road } \\
\text { accident prevention }\end{array}$ & 1.64 non-fatal injuries \\
\hline Payback period & 0.71 mln RUB \\
\hline \multicolumn{1}{|c|}{ Medium-cost actions } & Costs: 4,617,134.44 \\
\hline
\end{tabular}

\begin{tabular}{|c|c|}
\hline $\begin{array}{l}\text { Approximate assessment of } \\
\text { impact, reduction in the number } \\
\text { of registered road accidents }\end{array}$ & $-68 \%$ \\
\hline \multirow{2}{*}{$\begin{array}{l}\text { Expected annual effect in case } \\
\text { of implementation of actions; } \\
\text { reduction by: }\end{array}$} & 0.68 fatalities \\
\hline & 2.72 non-fatal injuries \\
\hline $\begin{array}{l}\text { Annual savings in case of road } \\
\text { accident prevention }\end{array}$ & $12.84 \mathrm{mln}$ RUB \\
\hline Payback period & 4.3 months \\
\hline High-cost actions & Costs: $14,933,319.84$ \\
\hline $\begin{array}{l}\text { Approximate assessment of } \\
\text { impact, reduction in the number } \\
\text { of registered road accidents }\end{array}$ & $-93 \%$ \\
\hline \multirow{2}{*}{$\begin{array}{l}\text { Expected annual effect in case } \\
\text { of implementation of actions; } \\
\text { reduction by: }\end{array}$} & 0.93 fatalities \\
\hline & 3.72 non-fatal injuries \\
\hline $\begin{array}{l}\text { Annual savings in case of road } \\
\text { accident prevention }\end{array}$ & $17.56 \mathrm{mln}$ RUB \\
\hline Payback period & 10 months \\
\hline
\end{tabular}

\section{Conclusions}

During road construction, it is necessary to follow construction regulations and take into account the relief and climate of the district. In the course of further road maintenance, condition of the following road infrastructure facilities' parameters shall be monitored: qualitative and quantitative characteristics of the traffic flow, vehicle braking processes, road structure strength as per the modulus of elasticity, identification of black spots as per the risk of their formation, their impact on accident rate prediction.

Analysis of the data obtained diagnostically and processed with analytical and computational methods allows obtaining actual results regarding traffic safety condition and compliance of parameters with applicable regulations. Obtaining actual results regarding parameters allows developing actions aimed at elimination of black spots and accident rate decrease. Such actions also allow predicting road accident risk formation, improving reliability of conclusions and accuracy of calculations in expert reports. 


\section{References}

Domke, E.R. (2012). Rassledovanie i ekspertiza dorozhno-transportnykh proisshestvii [Investigation and expert examination of road accidents], 2nd edition. Moscow: Publishing Center "Akademia", p. 288. (in Russian)

Evtyukov, S.A., Vasiliev, Ya.V. (2012). Dorozhno-transportnye proisshestviia: rassledovanie, rekonstruktsiia, ekspertiza [Road accidents: investigation, reconstruction, expert examination]. Saint Petersburg: Publishing House "DNK", p. 392. (in Russian)

Federal State Budgetary Institution ROSDORNII (2015). Rekomendatcii po uchetu i analizu dorozhno-transportnykh proisshestvii na avtomobilnykh dorogakh Rossiiskoi Federatcii. ODM 218.6.015-2015 [Recommendations for accounting and analysis of road accidents on the roads of the Russian Federation. ODM 218.6.015-2015]. (in Russian)

Ilarionov, V.A. (1989). Ekspertiza dorozhno-transportnykh proisshestvii [Expert examination of road accidents]. Moscow: Transport, p. 255. (in Russian)

Kurakina, E.V., Evtyukov, S.A. (2014). Sovershenstvovanie algoritma avtotekhnicheskoi ekspertizy pri rekonstruktsii DTP, uchityvaiushchei tekhnicheskoe sostoianie transportnogo sredstva i dorogi [Improvement of the algorithm of technical expert examination of motor vehicles during reconstruction of road accidents with account for the technical condition of vehicles and roads]. In: Proceedings of the 11th International Conference "Organization and Traffic Safety Management in large cities", pp. 518-527. (in Russian)

Kurakina, E.V., Evtyukov, S.A. (2015). Issledovanie stcepnykh kharakteristik dorozhnogo pokrytiia pri avtotekhnicheskoi ekspertize DTP [Analysis of adhesion characteristics of road surfaces during technical expert examination of motor vehicles upon road accidents]. Vestnik grazhdanskikh inzhenerov [Bulletin of Civil Engineers], 5 (52), pp. 216-223. (in Russian)

Kurakina, E.V., Evtyukov, S.A. (2017). Improvement of the system for accounting of parameters during construction of motor roads. Architecture and Engineering, 2(3), pp. 34-42. DOI: 10.23968/2500-0055-2017-2-3-34-42

Kurakina E.V., Evtyukov S.S., Golov E.V. (2017). Rekonstruktciia dorozhno-transportnykh proisshestvii [Reconstruction of road accidents]. Saint Petersburg: Publishing House "Petropolis". (in Russian)

Kurakina, E., Evtyukov, S., Lukinskiy, V., Ushakov, A. (2017). Methodology for the reconstruction and investigation of causes of accidents in the parameters of vehicle condition and road environment. Transportation Research Procedia, 20, pp. 185-192. DOI: 10.1016/j.trpro.2017.01.049

Kurakina, E.V. (2013). Ekspertnaia kharakteristika avtomobilnoi dorogi v dorozhno-transportnoi ekspertize [Expert review of roads in road traffic expert examination]. Modern problems of science and education, 5. Available at: http: //www.scienceeducation.ru/111-r10273 (accessed on: 29.01.2018). (in Russian)

Kurakina, E.V. (2014a) Nauchno-metodicheskoe obespechenie avtotekhnicheskoi ekspertizy, uchityvaiushchei tekhnicheskoe sostoianie avtomobilia i dorozhnoi sredy [Scientific and methodological support of technical expert examination of motor vehicles with account for the technical condition of vehicles and road environment]. PhD Thesis in Engineering. Saint Petersburg, p. 203. (in Russian)

Kurakina, E.V. (2014b). Issledovanie sostoianiia bezopasnosti i kachestva podsistemy [Investigation of safety and quality of the "Road" subsystem]. In: Proceedings of the International Scientific and Technical Conference "Engineering Science 2014: theory, education, practice and innovations", pp. 232-244. (in Russian)

Kurakina, E.V. (2014c). Ob otklonenii normativnykh kharakteristik pokazatelei avtomobil'noi dorogi (na primere avariino-opasnykh uchastkov dorog Leningradskoi oblasti) [On deviations of standard characteristics of the road (case study of accident clusters of roads in the Leningrad Region)]. Modern problems of science and education, 2, p. 118. (in Russian)

Kurakina, E. V. (2016). Diagnosticheskoe issledovanie elementov avtomobil'nykh dorog na uchastkakh DTP nerazrushaiushchim kontrolem [Diagnostic work-up of the motor road elements at the site of traffic accident by nondestructive testing technique]. Vestnik grazhdanskikh inzhenerov [Bulletin of Civil Engineers], 6 (59), pp. 231-237. (in Russian)

Kurakina, E. V. (2017). Sovershenstvovanie algoritma dorozhno-transportnogo issledovaniia nerazrushaiushchim metodom [Improvement of the algorithm of road and transport investigation in a non-destructive method]. Vestnik grazhdanskikh inzhenerov [Bulletin of Civil Engineers], 1 (60), pp. 262-269. (in Russian)

Suvorov, Yu.B., Kikot, I.M., Khapatnyukovsky, M.V., Kovalenko, L.A., Kilienko, I.I. (1990). Diagnosticheskoe issledovanie elementov avtomobil'nykh dorog na uchastkakh dorozhno - transportnykh proisshestvii (dorozhnykh uslovii), vliiaiushchikh na bezopasnost' dorozhnogo dvizheniia [Diagnostic study of road elements at sections of high accident rate (road conditions) affecting road safety]. Moscow: All-Union scientific research institute of judicial investigation, p. 96. (in Russian)

Vasiliev, A.P. (2005). Spravochnaia entsiklopediia dorozhnika [Encyclopedia for road workers], vol. 1. Moscow: Informavtodor. (in Russian) 